\title{
New Forest Dynamics working group
}

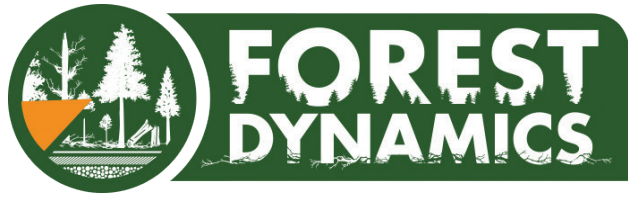

Jennifer Clear ${ }^{1,2}$, R. Chiverrell ${ }^{3}$, R. J. DeRose ${ }^{4}$, I. Drobyshev ${ }^{5,6}$, J. Morris $^{7}$ and M. Svoboda ${ }^{1}$

Forest dynamics are driven by an array of disturbances both natural (e.g. fire, windstorms, pathogens) and anthropogenic (e.g. clear cutting, selective logging, slash-andburn) in origin. Evidence of these events is recorded in sediments (lakes and mires; Fig. 1), dendroecology (tree ring) records, and forestry inventory data. Natural disturbances are fundamental for vital functioning of forest ecosystems, and their impacts (e.g. frequency, severity, spatial pattern) change in response to increasing climatic and anthropogenic pressures. Understanding the disturbance dynamics of the past, present and future is critical research to better inform forest conservation and management (Morris et al. 2015).

The primary aim of the new Forest Dynamics working group is data integration across disciplines, combining the knowledge gained from sediment geochemistry and paleoecology records with that from dendroecology, dendrochronology and monitored forest inventories. Such integration should improve our understanding of forest disturbance dynamics via better proxy calibration and analyses across these different environmental archives. Ultimately, information from these combined resources can contribute to enhance policymaking and land management.

\section{Scientific objectives}

The objectives of Forest Dynamics are to: (1) build a spatial geodatabase of reconstructed disturbance histories from the sedimentary and dendrochronological records; (2) combine these disturbance histories by compiling, extrapolating and integrating short-term data onto a common time series; and using well-dated and process-validated calibrated sediment data to extend the knowledge of forest disturbance dynamics from dendroecological to millennial timescales; and (3) assessing the emergent spatial and temporal patterns in forest dynamics related to fire, wind and pathogen disturbances in context of potential shifting drivers of vegetation dynamics (e.g. climate and humans).

Forest Dynamics aims to unite global research communities by linking the multiple temporal scales of paleoecology and bridging the scale difference between sedimentary records and dendroecological records of forest disturbances. Our integrated geodatabase will enable improved interpretation of forest disturbances and help identify limitations in current data coverage. By uniting existing and facilitating new research projects, we aim to improve the spatial coverage and temporal resolution of research into natural and anthropogenically driven forest dynamics.

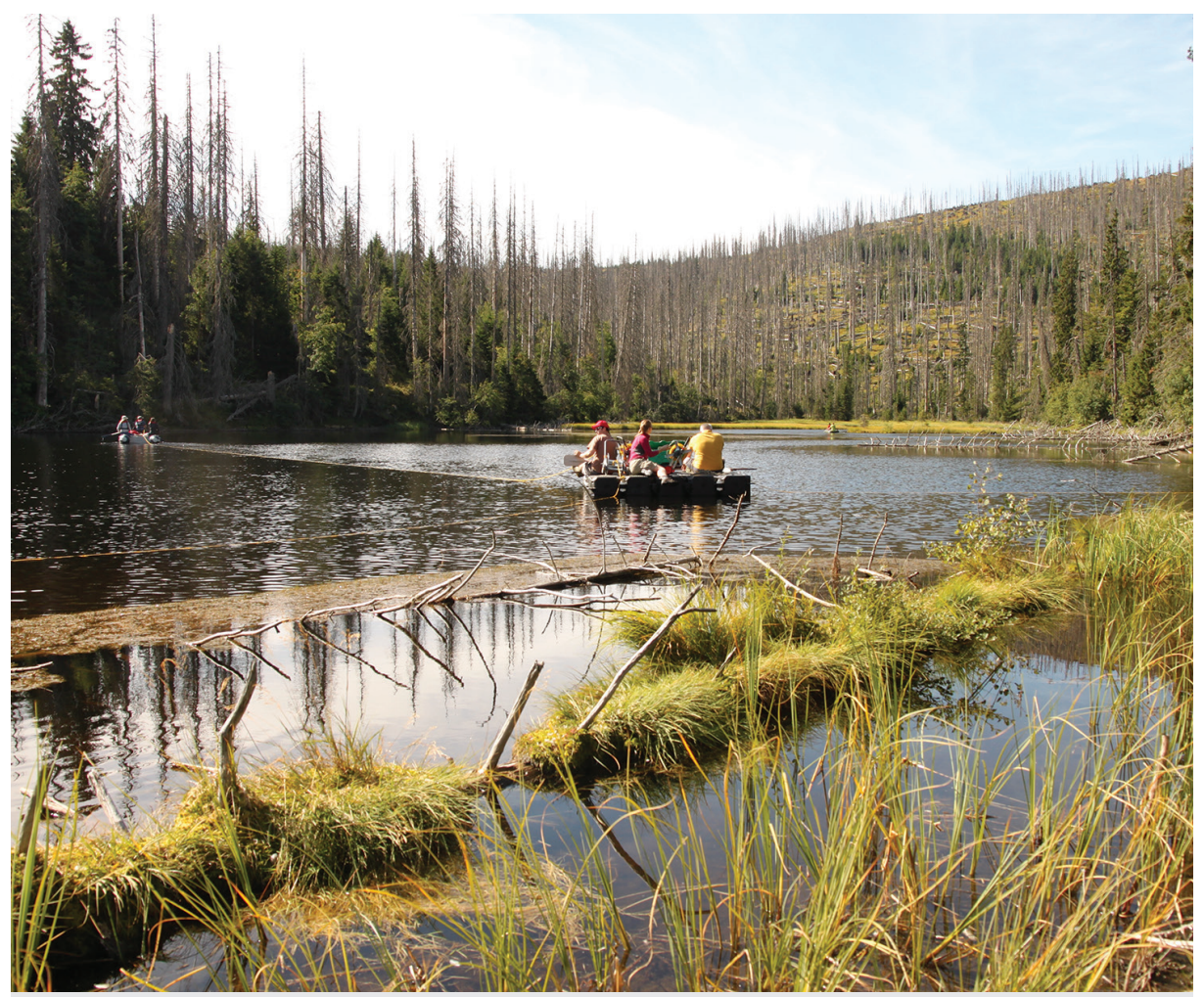

Figure 1: Lake sediment coring in a Spruce bark beetle disturbed catchment at Jezero Laka, Czech Repulic. Photo: Petr Kuneš.

The Forest Dynamics working group includes an expansive network of international scientists and key participants. We wish to expand our working group and seek global representation from scientists interested in all aspects of forest dynamics (forest succession and development, disturbance dynamics and catchment responses) including tropical, temperate and boreal forests.

Visit the Forest Dynamics website at: http:// pastglobalchanges.org/ini/wg/forest-dynamics/intro and join our mailing list to keep up to date with our activities.

\section{Upcoming activities}

Workshop (spring 2017 Løvenholm Castle, Denmark) will bring together researchers with interests in forest disturbance (sedimentary geochemists, paleoecologists and dendroecologists) with the aim to bridge the gap between these research communities and produce a comprehensive review paper titled "Mind the gap: challenges and progress in forest disturbance science".

AGU Fall Meeting (12-16 December 2016 San Francisco, USA) - B005 Alteration of disturbance-driven forest dynamics under a changing climate (Session 12625) https://agu. confex.com/agu/fm16/preliminaryview.cgi/ Session12625
PAGES OSM (9-13 May 2017, Zaragoza, Spain) - Session 5: Disturbance dynamics across spatial and temporal scales: fire, wind, pathogens and post-disturbance run off as drivers of environmental change www. pages-osm.org/osm/sessions-osm

\section{AFFILIATIONS}

'Department of Forest Ecology, Czech University of Life Sciences, Prague, Czech Republic

${ }^{2}$ Department of Marine and Coastal Sciences, Rutgers University, New Brunswick, USA

${ }^{3}$ Department of Geography and Planning, University of Liverpool, UK

${ }^{4}$ Rocky Mountain Research Station, US Forest Service, Ogden, USA

${ }^{5}$ Swedish University of Agricultural Sciences, Southern Swedish Forest Research Centre, Alnarp, Sweden

${ }^{6}$ Chaire industrielle en aménagement forestier durable, Université du Québec en AbitibiTémiscamingue, Rouyn-Noranda, Canada ${ }^{7}$ Department of Forest, Rangeland, and Fire Sciences, University of Idaho, Moscow, USA

\section{CONTACT}

Jennifer Clear: jenniferlclear@gmail.com REFERENCES

Morris et al. (2015) For Ecosyst 2, doi: 10.1186/ s40663-015-0057-0 